ISSN: 2146-3042

DOI: $10.25095 /$ mufad.710240

\title{
Mesleki ve Teknik Anadolu Liselerinde Muhasebe Eğitimi, Muhasebe Eğitiminden Beklentiler ve Karşılaşılan Sorunlar: Ağrı ve Erzurum İllerinde Bir Araştırma*
}

\author{
Utku ŞENDURUR**
}

\section{$\ddot{O Z Z E T}$}

Çalışmanın temel amacı Mesleki ve Teknik Anadolu Liselerinde verilen muhasebe eğitimini incelemek, muhasebe eğitiminden beklentileri ve karşılaşılan sorunları ele alarak sorunlara ilișkin çözüm önerileri getirmeye çalışmaktır. Muhasebe eğitiminden beklentileri ve karşılaşılan sorunları belirlemek için Mesleki ve Teknik Anadolu Liselerinde işletmelerde beceri eğitimi gören muhasebe bölümü son sınıf öğrencilerine yönelik bir anket hazırlanmıştır. Araş̧ırmanın ana kütlesini 2017-2018 eğitim-öğretim yılında Ağrl ve Erzurum illerinde bulunan Mesleki ve Teknik Anadolu Liselerinde eğitim gören toplam 310 muhasebe bölümü son sınıf ögrencileri oluşturmaktadır. Hazırlanan anketler, farklı liselerden rasgele seçilen 260 ögrenciye uygulamıştır. Anketler vasıtasıyla elde edilen verilerdenSPSS 25 programı kullanılarak frekans ve yüzde analizi yapılmış ve ortalama puanlara bakılmıştır. Elde edilen bulgulara dayalı olarak öneriler getirilmeye çalışılmıştır. Araştırmadan elde edilen sonuçlara göre, ögrencilerin muhasebeyi sevmediği, beceri eğitiminde muhasebe dışı işlerde çalıştırıldıkları, okutulan kültür derslerinin yetersiz olduğu ve okullardaki araç gereçlerin ihtiyacı karşılamadığı gibi konularda sorunlar olduğu tespit edilmiş, bu sorunlara ilişkin çözüm önerileri sunulmuştur.

Anahtar Kelimeler: Muhasebe Eğitimi, Mesleki ve Teknik Anadolu

Liseleri, Yüzde ve Frekans Analizi.

JEL Sinıflandırması: M41, A20, C83.

Accounting Education, ProspectsFrom Accounting Education and Problems Encountered in Vocational and Technical Anatolian High Schools: A Survey on Ăgrı and Erzurum Provinces

\section{ABSTRACT}

This study aim sto examine the education at Vocationaland Technical AnatolianHigh Schools and to attempttosuggest solutions to problems encountered from accounting education at the schools mentioned above by analyzing these problems and expectations from accounting education. A survey for310 senior (12 th) grade students who also do internship in accountign courses is conducted. A random sample of 260 student sare determined from Erzurum and Agri Vocational and Technical Anatolian High Schools in the academic year of 2017-2018 for the survey questionnaire. Frequency, proportion and mean analysis is done with SPSS 25 software. The results show that some problems like dislike of accounting, working at jobs unrelated to accounting during internship period, inadequate cultural courses in school and insufficien tcourse material are most likely to occur during the accounting education at these schooland try to suggest some solutions to those problems. Analysis.

Keywords: Accounting Education, Vocationaland Technical Anatolian High Schools, Frequency and Proportion

Jel Classification: $M 41$, A20, C83

\footnotetext{
* Bu çalışma 6. Uluslararası Çin'den Adriyatik’e Sosyal Bilimler Kongresinde bildiri olarak sunulmuştur. Makale Gönderim Tarihi: 16.04.2019, Makale Kabul Tarihi: 17.07.2019, Makale Türü: Araştırma Makalesi ** Dr. Öğr. Üyesi, Ağrı İbrahim Çeçen Üniversitesi, İktisadi ve İdari Bilimler Fakültesi, usendurur@agri.edu.tr, Orcid ID: 0000-0002-8303-4315.
} 


\section{GíRiş}

Muhasebe, bir örgütün kaynaklarının oluşumunu, bu kaynakların kullanılma biçimini, örgütün işlemleri sonucunda bu kaynaklarda meydana gelen artış ve azalışları ve örgütün finansal açıdan durumunu açıklayan bilgileri üreten ve bunları ilgili kişi ve kuruluşlara ileten bir bilgi sistemidir(Sevilengül, 2016). Bu sistem içerisindeki süreçte yapılması gereken kaydetme, sınıflama, özetleme ve raporlama işlerini ise muhasebe eğitimi almış, muhasebe meslek mensupları yaparlar. Muhasebe sisteminin eksiksiz, hatasız ve doğru bir biçimde işlemesi, kuşkusuz iyi bir mesleki eğitim almış meslek mensuplarıyla olur.

Mesleki eğitim, kişinin belirli bir mesleği icra etmesi ve icra ettiği bu meslekte belirli bir düzeye ulaşması için gerekli yeterliliğe, meslek kültürüne ve meslek etiğine sahip olmasını mümkün kılan eğitimdir (Pehlivan \& Karlıkl1, 2018).Mesleki eğitimin önemli alanlarından biri de, artan rekabet, teknolojik gelişmeler, değişen vergi politikaları ve işletme sayılarının sürekli artmasıyla beraber çok geniş bir alana yayılan muhasebe uygulamaları nedeniyle, muhasebe eğitimidir. Globalleşen dünyada, muhasebeden sağlanan verilere ihtiyaç, gün geçtikçe artmış ve muhasebe, finansal hayat için çok daha önemli bir hale gelmiştir (Özkan \& Aksoy, 2015). Muhasebenin öneminin bu derece artması ile beraber şüphesiz amacı mesleğin getirdiği bilgi ve beceriyi uygulamalı olarak aktarma olan muhasebe eğitimi de son derece önemli bir hale gelmiştir (Gönen, 2016). Finansal verileri doğru bir ş̧ekilde analiz etmek, anlaşılır ve güvenilir bir şekilde ilgi duyanlara raporlamak için iyi bir muhasebe eğitimi alınması gerekmektedir. İște bu eğitim, Türkiye'de ortaöğretim düzeyinde,Mesleki ve Teknik Anadolu Liseleri(Ticaret Meslek Liseleri) ve çok programlı Anadolu Liselerinde verilmeye başlanmaktadır.

Mesleki ve Teknik Anadolu Liseleri, ekonominin ve ticaret eğitiminin bilinçli ve bir sisteme bağlı olarak verildiği, ilköğretim üzerine dört yıl öğrenim süresi olan ve gün geçtikçe önemini arttıran meslek liseleridir (Akbulut, Pekkaya, \& Aksakaloğlu, 2014:73). Mesleki ve Teknik Anadolu Liselerinde verilen muhasebe eğitimi; muhasebe ve finansman alanı altında, bilgisayarlı muhasebe, dış ticaret ofis hizmetleri ve finans ve borsa hizmetleri olarak üç dala ayrılmıştır. Bu alanda öğrenim gören öğrenciler, işletmenin kuruluşu, muhasebe kayıtları, analiz ve raporlama yapma, ticaret mevzuat, finans ve borsa hizmetleri gibi konularda bilgi sahibi olurlar (Özkan \& Aksoy, 2015). Öğrenciler ayrıca mesleki beceri eğitimi (staj) de alarak teorik eğitimde öğrendikleri konuları iş dünyasında uygulama firsatı bulurlar.

Mesleki ve Teknik Anadolu Liseleri, mesleki eğitimin başladığı ilk kurum olması yönünden çok önemli bir konumdadır. Burada verilen eğitimin nitelik ve niceliği, iş yaşamına kadar devam eden diğer süreçleri de derinden etkileyecektir. Gelişmiş ülkelerde de Mesleki ve Teknik Anadolu Liselerinebüyük önem verilmiştir. ABD'nin 1917 yllında Meslek Liseleri'ni ulusal meselelerde birinci öncelik olarak belirlemesi bunun en güzel örneğidir (Silverberg, Warner, Fong , \& Goodwin, 2004).Mesleki ve Teknik Anadolu Liselerininönemini arttıran bir diğer husus, henüz öğrenim hayatının başında bulunan bireylerin teknolojik değişime de kolay ayak uydurabilmesidir. Günümüzde teknolojinin hızla değişmesi, muhasebe mesleğine de yansımaktadır (Howieson, 2003:69). 2005 yılında uygulamaya koyulan Mesleki ve Teknik Eğitimi Geliştirme Projesi (MEGEP) sayesinde oluşturulanmodül sistemi ile, değişime ayak uydurabilen, içinde bulunduğumuz çağın niteliklerine sahip bireyler yetiştirilmeye başlanmıştır. Mesleki ve Teknik Anadolu Liseleriniönemli kılan bir başka konu ise, burada verilen beceri eğitimidir. Yapılan birçok araştırma, beceri eğitiminin, kişinin ileriki mesleki 
hayatına çok büyük bir katkısı olduğu sonucunu bulmuştur (Burnett, 2010:129).Günümüzde verilen eğitim ve mesleki yeterlilik arasında büyük bir uçurum olduğu görülmektedir (Porter \& Bui, 2010:23).Muhasebe eğitiminin temellerinin atıldığ 1 Mesleki ve Teknik Anadolu Liselerindeverilecek olan çağdaş eğitim ve devamında gelen süreç ile birlikte bu boşluğun da kapanacağı düşünülmektedir.

Her alan ve kurumda olduğu gibi, Mesleki ve Teknik Anadolu Liseleri ve burada verilen muhasebe eğitiminde de birtakım sorun ve eksiklikler vardır. Çalışmada, muhasebe eğitiminin temel taşını oluşturan Mesleki ve Teknik Anadolu Liselerindemuhasebe eğitiminden beklentiler ve karşılaşılan sorunlar araştırılacak, birtakım çözüm önerileri sunulacaktır.

\section{LITERATÜR TARAMASI}

Literatür incelendiğinde, üniversite ve Mesleki ve Teknik Anadolu Liselerindemuhasebe eğitimini, muhasebe eğitiminden beklentileri ve karşılaşılan sorunları araştıran birçok çalışma olduğu görülmektedir. Bonwell ve Eison (1991), muhasebe eğitiminde çağdaşlaşma ile ilgili çalışmalar yapmışlar ve çağdaş eğitim metotları ile ilgili birtakım stratejiler ortaya koymuşlardır. Kunt (1992) tarafından meslek liselerinde beceri eğitiminde karşılaşılan sorunların belirlenmesine yönelik yapılan çalışmada birçok sorunun varlığına değinilmiş̧tir. Cottell ve Millis (1993:40), muhasebe eğitiminde geleneksel eğitimin rolü, Özgül (1995) ise Kunt'un çalışmasının bir benzeri olan meslek liselerinde beceri eğitiminde karşılaşılan sorunlar konulu çalışmalar yapmışlardır.

Demirkan (2001), muhasebe eğitiminde teori ve pratiğin aynı öneme sahip olduğu sonucunu ortaya koyan bir çalışma yapmıştır. Karaca (2003), tarafından yapılan çalışmada meslek yüksekokullarında muhasebe eğitimi alan öğrencilerin eğitimlerinin iş dünyası tarafından yeterli görülmediği belirtilmiştir. Kalmış ve Yılmaz (2004), Özpeynircivd (2004), Kaya ve Daştan (2004), yaptıkları çalışmalarından çıkan ortak sonuç, muhasebe öğretim yöntemlerinin yetersiz olduğu, derslerin anlaşılamadığı ve eğitim kalitesinin düşük olduğudur. Akman ve Mungan (2004) ve Çaldağ vd. (2004), çalışmalarının ortaya koyduğu bulgulardan yola çıkarak, artık geleneksel öğretim yöntemlerini bırakıp, öğrenci odaklı ve daha dinamik olan çağdaş öğretim yöntemlerinin benimsenmesi gerektiğini savunmuşlardır.Byrne ve Flood (2005:111), muhasebe öğrencilerinin beklentileri ve motivasyonları üzerine yaptıkları çalışmalarında, öğreticilerin, öğrencilerinin beklentilerinin farkında olmadığı sonucunu bulmuştur. Erol (2006:136), meslek yüksekokullarında beceri eğitimi üzerine bir çalışma yaparken, Bekçi vd. (2006:166), muhasebe eğitiminde teknolojinin ve paket programlarınönemini açıklayan bir çalışma yapmışlardır.Tekşen vd. (2007), meslek yüksekokulu muhasebe öğrencileri üzerine yaptıkları araştırmada ortaya çıkan sonuçlara göre, öğrenciler öğretim elemanlarının bilgi birikiminin yetersiz olduğu görüşünde birleşmişlerdir. Kaytmazbalsarı ve Aslantürk (2007)'ün çalışmalarında ise öğrenciler teorik bilgilerin yanı sıra, problem çözme ve takım halinde çalışma gibi konularda da eğitim almak istediklerini belirtmişlerdir. Sürer (2007) yaptığı çalışmasında, öğrencilerle birlikte, Mesleki ve Teknik Anadolu Liselerindegörev alan muhasebe öğretmenlerine de anket uygulamıştır. Çalışma sonuçlarında, kaynakların yetersizliği, teknolojik imkansızlıklar ve gerçek defterler üzerinde kayıt yapamama gibi sorunların varlığı belirlenmiştir. Gökgöz (2007) ve Demirci (2007), Mesleki ve Teknik Anadolu Liseleri öğrencilerinin beceri eğitimi alırken karşılaştı̆̆ problemlere yönelik çalışmalar yapmışlardır. Çalışmalarda ortaya çıkan sonuçlara göre, 
verilen teorik eğitim ile beceri eğitimi uygulamalarının örtüşmediği görülmüştür. Pehlivan (2008)'in Mesleki ve Teknik Anadolu Liselerindemuhasebe eğitimi alan öğrencilerin memnuniyeti üzerine yaptığı çalışmada, öğrencilerin aldıkları eğitimden memnun oldukları sonucu çıkarken, Çamtosun (2008)'un çalışmasında da öğrenciler, Mesleki ve Teknik Anadolu Liselerindemuhasebe eğitiminin yeterli düzeyde olduğunu belirtmişlerdir. Yardım (2009)'ın çalışmasında ise, işverenlerin beceri eğitimi alan öğrencilerden memnuniyeti, orta düzeyde kalmıştır.

Şengel (2010:81)'un çalışmasında Türkiye'de muhasebe eğitimi veren kurumların kalitesinin gün geçtikçe arttığı sonucu ortaya çıkmıştır. Bay (2010) ve İmamoğlu (2010), çalışmalarında MEGEP'nin sağladığı yararlar ve ortaya çıkan sorunlara değinmiş, birtakım çözüm önerileri sunmuşlardır. Yılmaz (2011) yaptığı çalışmasında Mesleki ve Teknik Anadolu Liselerindekibeceri eğitimine değinmiş ve bu eğitimin öğrencilere iş disiplini ve ahlakı kazandırdığı sonucuna ulaşmıştır.Gökgöz ve Kırlığlu (2011) ise çalışmalarında, beceri eğitimi alan öğrencilerin alanları dışındaki işlerde çalıştırıldıkları ve ücretlerini tam alamadıkları gibi sorunlarla karşılaştıklarını belirlemişlerdir. Otlu vd. (2012:35), yaptıkları çalışmada meslek yüksekokulu öğrencilerinin burada aldıklarıeğitimle beraber fiziki ve sosyal imkanları da yetersiz bulduğunu belirtmişlerdir. Aksakaloğlu (2013)'nun çalışmasında ortaya çıkan sonuca göre, öğrencilerin iş hayatına uyum sağlamakta zorlandığ 1 görülmüştür. Soylu (2014), muhasebe eğitiminde karşılaşılan problemleri incelemiş ve eğitim kalitesinin yükseltilmesine yönelik önerilerde bulunmuştur. Tuğay (2014:49), çalışmasında öğretim elemanlarının teknolojiyi daha etkin kullanması gerektiğini, Ertuğrul ve Özdemir (2014:204) çalışmalarında, öğrencilerin muhasebe dersini sevmediğini, Tuğay ve Ömürbek (2014:53) çalışmalarında, verilen eğitimde muhasebe paket programları kullanımının yetersiz olduğunu, Atmaca ve Çoşgun (2014:167) çalışmalarında, öğrencilerin muhasebe bölümünün kariyer fırsatlarının yeterli olmadığını düşündüklerini, Çakır vd. (2014:78) çalışmalarında, öğrencilerin muhasebe dersinde zorlandıklarını, Zamanianfar vd. (2014:298) çalışmalarında, muhasebe eğitiminde en önemli özelliğin iletişim olduğunu, Akbulut vd. (2014) ise, Mesleki ve Teknik Anadolu Liselerindeverilen eğitimin, meslek mensubu olmada yetersiz olduğunu belirtmişlerdir. Teixeira vd. (2015:123), yaptıkları çalışmada muhasebe öğrencilerinin motivasyon ve beklentilerini araştırmışlardır. Çalışma sonuçlarına göre, muhasebe öğrencileri, diğer bölümlerde eğitim gören öğrencilere göre iş hayatına daha az hazırlıklıdır. Özkan ve Aksoy (2015:283)'un çalışmalarında, Mesleki ve Teknik Anadolu Liselerindekibeceri eğitimi sırasında karşılaşılan sorunlara çözüm önerileri sunulmuştur. Gönen (2016:67), önlisans öğrencilerinin muhasebe eğitiminden beklentileri üzerine yaptığ1 çalışmasında, öğrencilerin sorumluluk ve mesleki saygınlık sebebiyle muhasebecilik mesleğini seçtiğini belirtmiştir. Pehlivan ve Karlıklı (2018:151), Mesleki ve Teknik Anadolu Liselerindeverilen muhasebe eğitiminin muhasebecilik mesleğine uygunluğu konulu çalışmalarında, öğrencilerin bu okullardaki mevcut muhasebe eğitimiyle mesleği icra edemeyeceği ve bu kurumlardaki muhasebe eğitiminin yeniden yapılandırılması gerektiğini söylemişlerdir.

Literatürde, lisans ve önlisans düzeyinde muhasebe eğitimi ile birçok çalışma olduğu görülmüş̧ür. Mesleki ve Teknik Anadolu Liselerindeise daha çok beceri eğitimi konuları ile ilgili araştırmalar yapılmıştır. Mesleki ve Teknik Anadolu Liselerindemuhasebe eğitimi, karşılaşılan sorunlar ve çözüm önerilerine ilişkin çalışmalar nispeten daha azdır. Bu konu ile 
ilgili Erzurum ve Ağrı illerinde yapılan bir çalışmaya ise rastlanamamıştır. Çalışmanın bu yönüyle literatüre katkı sağlayacağı düşünülmektedir.

\section{3. ÇALIŞMANIN AMACI VE ÖNEMİ}

Çalışmanın amacı, öğrenci görüşlerine göre Mesleki ve Teknik Anadolu Liselerinde verilen muhasebe eğitiminin, öğrencilerin mesleki bilgi ve becerilerinin gelişiminde yeterli olup olmadığını tespit etmek ve bu sorunlara ilişkin çözüm önerileri getirmektir.

Literatürde, Mesleki ve Teknik Anadolu Liselerinde muhasebe eğitimi, karşılaşılan sorunlar ve çözüm önerilerine ilişkin az sayıda çalı̧̧maya rastlanmıştır. Çalışmanın literatürdeki bu boşluğu doldurması yönüyle önemli olduğu düşünülmektedir.

\section{4. ÇALIŞMANIN VERİ SETİ VE YÖNTEMI}

Çalışmanın bu bölümünde araştırmanın veri seti ve yöntemine ilişkin bilgiler verilmiştir. Çalışmada Mesleki ve Teknik Anadolu Liselerinde muhasebe eğitimi, muhasebe eğitiminden beklentiler ve karşılaşılan sorunlar öğrencilere uygulanan anket yardımı ile araştırılmış, ortaya çıkan sonuçlar yüzde ve frekans dağılımı yöntemi ile analiz edilmiş̧ir. $\mathrm{Bu}$ çalışma Çiftçi ve Çemrek (2018:192)'in çalı̧masındaki ölçekten esinlenilerek yapılmıştır.

\subsection{Veri Seti}

Çalışmada kullanılan veriler 2018 yılına Erzurum ve Ağrı ilinde eğitim gören Mesleki ve Teknik Anadolu Liselerine anket uygulanarak elde edilmiştir. Toplam öğrenci sayısı 310, ankete katılan ve eksik veriler çıkarıldıktan sonra ulaşılan öğrenci sayısı 260 kişidir. Çalışmada, ankete katılan öğrencilerin sosyo-demografik özelliklerinin tespiti, Mesleki ve Teknik Anadolu Liselerine girme nedenlerinin belirlenmesi, üniversite seçimleri ve beceri eğitimleri hakkında 8 soru; muhasebe eğitimi, muhasebe eğitiminden beklentiler ve karşılaşılan sorunlar ile ilgili de $5^{\prime}$ li likert ölçeği kullanılarak hazırlanan 16 soru yer almaktadır. Yapılan analizlere göre veriler normal dağılmıştır (sig: 0.000). Anketin güvenilirlik analizi için yapılan Cronbach Alpha $(\alpha)$ analiz değeri ise $0.795^{\prime}$ tir. Bu değer $0.8^{\prime} \mathrm{e}$ çok yakın olduğu için, uygulanan anketin yüksek güvenilirliğe sahip olduğu söylenebilir.

\subsection{Yöntem}

Çalışmada yüz yüze görüşme yöntemi ile öğrencilere anket uygulanmış ve araştırma sonucunda elde edilen veriler SPSS 25 paket programına aktarılarak frekans ve yüzde dağılımı ile ortalamalar gibi istatistiki yöntemlerle analiz edilmiștir. Ayrıca anket sorularına tek tek bakılarak gruplar arası anlamlı bir fark olup olmadığını gösteren farklılık analizi de (ttesti) yapılmıştır.

\section{BULGULAR VE YORUMLAR}

Öğrencilerin anket sorularına verdikleri cevaplara göre yapılan değerlendirmeler tabloların altında yer almaktadır. Ankete katılan öğrencilere ait demografik bilgiler Tablo1 'de gösterildiği gibidir. 
Tablo 1. Demografik Özellikler

\begin{tabular}{lll}
\hline Cinsiyet & Frekans & Yüzde \\
\hline K1z & 95 & 36.5 \\
Erkek & 165 & 63.5 \\
\hline TOPLAM & $\mathbf{2 6 0}$ & $\mathbf{1 0 0}$ \\
\hline Gelir Düzeyi (TL) & Frekans & Yüzde \\
\hline $0-1000$ & 70 & 26.9 \\
$1001-2000$ & 100 & 38.5 \\
$2001-3000$ & 48 & 18.5 \\
$3001-4000$ & 14 & 5.4 \\
4001-5000 & 14 & 5.4 \\
5001 ve üstü & 14 & 5.4 \\
\hline TOPLAM & $\mathbf{2 6 0}$ & $\mathbf{1 0 0}$ \\
\hline
\end{tabular}

Ankete katılan öğrencilerin \%63,5'i erkek, \%36,5'i ise k1z öğrencilerden oluşmaktadır. Öğrencilerin büyük bir bölümünün (\%83.8) ailelerinin gelir düzeyi 3000 TL'nin altındayken, sadece \%16.2'sinin geliri 3000 TL'yi geçmektedir.Ortaya çıkan sonuçlara göre, Mesleki ve Teknik Anadolu Liselerinde öğrenim gören öğrenciler genellikle erkektir ve gelir düzeyleri düşüktür diyebiliriz.Öğrencilerin eğitim almasındaki amacı, Mesleki ve Teknik Anadolu Liselerini seçme nedenleri ve mezun olunca üniversite tercihi yapıp yapmayacakları; yaparlarsa hangi alanı seçeceklerine dair verdikleri cevaplar Tablo 2'de gösterilmiştir.

Tablo 2. Öğrencilerin Eğitim Tercihleri

\begin{tabular}{lll}
\hline $\begin{array}{l}\text { Mesleki ve Teknik Anadolu Lisesindeeğitim } \\
\text { almayı seçmenizde etkili olan nedenler nelerdir? }\end{array}$ & Frekans & Yüzde \\
\hline Ailem & 38 & 14.6 \\
Kendi tercihim & 123 & 47.3 \\
Çevremdeki mezunlar & 20 & 7.7 \\
Diğer & 79 & 30.4 \\
\hline Mesleki ve Teknik Anadolu Lisesindeeğitim & Frekans & Yüzde \\
almaktaki amacını nedir? & & \\
\hline Muhasebe meslek mensubu olmak & 43 & 16.5 \\
Meslekle ilgili bir işe girmek & 56 & 21.5 \\
Yüksek öğrenime snavsı geçiş yapmak & 16 & 6.2 \\
Sadece Mesleki ve Teknik Anadolu Lisesidiploması & 25 & 9.6 \\
sahibi olmak & & 46.2 \\
Diğer & 120 & Yüzde \\
\hline Üniversitede hangi alanda eğitim almak & Frekans & \\
istersiniz? & & 15.8 \\
\hline Muhasebe & 41 & 74.2 \\
Diğer & 193 & 10 \\
Üniversite eğitimi almak istemiyorum & 26 & \\
\hline
\end{tabular}


Anket sorularına verilen cevaplara göre öğrencilerin yarıya yakını (\%47.3)Mesleki ve Teknik Anadolu Liselerinde eğitim almayı kendileri seçmiştir. Ailelerinin ve çevresindeki mezunların bu karara etki oranı ise \%22.3'tür. Öğrenciler, Mesleki ve Teknik Anadolu Liselerinde eğitim almaktaki amacını nedir sorusuna \%38 oranla meslek mensubu olmak veya meslekle ilgili bir işe girmek yanıtını verirken; \%62'si sadece lise diploması almak, sınavsız bir şekilde üniversiteye girmek veya bunların dışında bir alternatif olan diğer seçeneğini seçerek yanıt vermişlerdir. Anket sonuçlarına göre ortaya çıkan bir diğer çarpıcı sonuç ise, Mesleki ve Teknik Anadolu Liselerinde eğitim alan öğrencilerin sadece \%15.8'inin üniversitede de muhasebe eğitimi almak istediklerini belirtmeleridir. Öğrencilerin \%74.2'si üniversitede muhasebe dışında bir alanı seçmeyi, \%10'u ise üniversite eğitimi almak istemediklerini belirtmişlerdir. Ankete katılan öğrencilerin yarıya yakını Mesleki ve Teknik Anadolu Liselerinde eğitim almayı kendilerinin seçtiğini söylemiş̧tir. Buna rağmen, \%74.2'si üniversitede faklı bölüm tercih etmek istediğini ve \%62'si de, muhasebe mesleği dışında bir meslek seçmeyi istediğini belirtmiş̧tir. Bu sonuçlar, Mesleki ve Teknik Anadolu Liselerindeverilen muhasebe eğitiminin sorgulanması gerekliliğini ortaya koymuş ve eğitimde birtakım sorunların olduğunu düşündürtmüştür.

Profesyonel muhasebe mesleğinde beceri eğitimi, kişilerin eğitim aşamasında ve sonrasında yerine getirmesi gereken önemli bir aşamadır (Uzay, 2005). Mesleki ve Teknik Anadolu Liselerinde, öğrenciler teorik derslerin yanında, eğitimin önemli bir bölümünü oluşturan, beceri eğitimi dersini de almaktadırlar. Öğrencilerin beceri eğitimi dersi ile ilgili verdikleri bilgiler Tablo 3’te yer almaktadır.

Tablo 3. Beceri Eğitimi

\begin{tabular}{lll}
\hline Beceri Eğitimi Yapılan İşletmenin Türü & Frekans & Yüzde \\
& & \\
\hline Muhasebe Bürosu & 135 & 51.9 \\
Kamu İ̧letmesi (Muhasebe) & 27 & 10.4 \\
Özel İşletme (Muhasebe bürosu dışında) & 36 & 13.8 \\
Diğer & 62 & 23.8 \\
\hline Beceri Eğitimi Yapılan İşletmeyi Belirleme Şekli & Frekans & Yüzde \\
\hline Kendim & 112 & 43.1 \\
Aile veya akraba yardımı ile & 69 & 26.5 \\
Okul yönetimi ve öğretmenlerin yardımı ile & 45 & 17.3 \\
Diğer & 34 & 13.1 \\
\hline Beceri eğitiminde muhasebe eğitiminin gerektiği işlerde mi & Frekans & Yüzde \\
görevlendiriliyorsunuz? & & \\
\hline Evet & 100 & 38.5 \\
& & 33.1 \\
Kısmen & 86 & 28.5 \\
Hayır & 74 & \\
\hline
\end{tabular}

Ankete katılan öğrencilerin verdikleri cevaplara bakıldığında, öğrencilerin \%43.1'inin beceri eğitimi yapılacak olan işletmeyi kendi çabaları ile bulduğu ve \%26.5'inin bu konu ile ilgili aile ve akrabalarının yardımını aldığı görülmektedir. Bu sonuçlara göre okul yönetiminin, beceri eğitimi yapılacak işletmeyi belirlerken, öğrencilere pek fazla yardımının olmadığı görülmüştür. Mesleki ve Teknik Anadolu Liselerinde muhasebe eğitimi alan öğrencilerin tamamının, beceri eğitimi alırken de muhasebe ile ilgili işletmelerde staj yapması 
beklenirken, ankete göre bu oran \%62.3'te kalmıştır. Bu oran zaten beklentilerin altında kalırken, beceri eğitiminde muhasebe eğitiminin gerektirdiği işlerde görevlendirilen öğrenci sayısı da \%38.5 olmuştur. Ortaya çıkan sonuçlara göre öğrenciler, beceri eğitimi yapacakları işletmeyi kendi imkanları ile bulmakta, bu işletmelerin yarıya yakını muhasebe ile ilgili işletmeler olmamakta ve öğrencilerin yarısından çoğu bu işletmelerde muhasebe dışı işlerde görevlendirilmektedirler.

Öğrencilerin Mesleki ve Teknik Anadolu Liselerinde verilen muhasebe eğitiminden beklentileri ve karşılaştıkları sorunlara ilişin görüşleri Tablo 4’te verilmiştir.

Tablo 4. Öğrenci Görüşleri

\begin{tabular}{|c|c|c|c|c|c|c|}
\hline SORULAR & 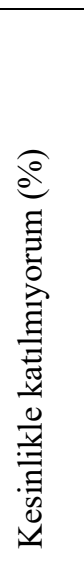 & 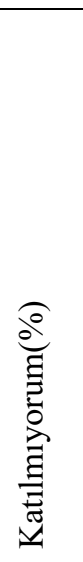 & 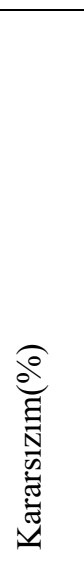 & 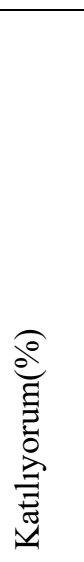 & 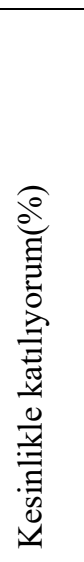 & \begin{tabular}{l}
\multicolumn{1}{c}{$\begin{array}{c}\text { ORTALAMAN } \\
\text { Pesinlikle }\end{array}$} \\
katılmiyorum=1 \\
Katılmiyorum \\
$=2$ \\
Kararsızım \\
$=3$ \\
Katıliyorum \\
$=4$ \\
Kesinlikle \\
katıliyorum =5
\end{tabular} \\
\hline $\begin{array}{l}\text { Okuldaki kültür derslerimiz bizi hayata hazırlama } \\
\text { açısından yeterlidir }\end{array}$ & 30 & 11.1 & 18.8 & 27.3 & 12.7 & 2.82 \\
\hline $\begin{array}{l}\text { Okuldaki meslek derslerimiz aldığımız muhasebe } \\
\text { eğitimi için yeterlidir }\end{array}$ & 13.1 & 19.2 & 24.6 & 24.2 & 18.8 & 3.17 \\
\hline $\begin{array}{l}\text { Muhasebe derslerinin ders saati sayısı aldığımız } \\
\text { muhasebe eğitimi için yeterlidir }\end{array}$ & 14.6 & 16.2 & 13.1 & 28.1 & 28.1 & 3.39 \\
\hline $\begin{array}{l}\text { Muhasebe ders kitapları aldığımız muhasebe eğitimi } \\
\text { için yeterlidir }\end{array}$ & 24.2 & 18.8 & 15.4 & 23.8 & 17.7 & 2.92 \\
\hline $\begin{array}{l}\text { Bilgisayarlı muhasebe dersi iş ve meslek hayatındaki } \\
\text { uygulamalar açısından yeterlidir }\end{array}$ & 14.6 & 16.9 & 21.2 & 30 & 17.3 & 3.18 \\
\hline $\begin{array}{l}\text { Okulda verilen muhasebe eğitimi ile işletmelerde } \\
\text { gördüğümüz beceri eğitimi birbirini } \\
\text { tamamlamaktadır }\end{array}$ & 16.2 & 15 & 29.6 & 22.7 & 16.5 & 3.08 \\
\hline $\begin{array}{l}\text { İşletmelerdeki beceri eğitimi esas amaçlar } \\
\text { doğrultusunda yapılmaktadır }\end{array}$ & 16.9 & 11.2 & 29.6 & 24.2 & 18.1 & 3.15 \\
\hline $\begin{array}{l}\text { İşletmelerdeki beceri eğitimi bizi iş ve meslek } \\
\text { hayatına hazırlamakta yeterlidir }\end{array}$ & 18.1 & 16.2 & 22.3 & 23.5 & 20 & 3.11 \\
\hline $\begin{array}{l}\text { Okulda aldığım muhasebe eğitimi sonucu kendimi } \\
\text { gerçek defterlere kayıt yapabilecek seviyede } \\
\text { görüyorum }\end{array}$ & 18.8 & 12.7 & 25.4 & 24.2 & 18.8 & 3.12 \\
\hline $\begin{array}{l}\text { Beceri eğitimi sırasında gerçek defterlere kayıt } \\
\text { yapma imkanı veriliyor }\end{array}$ & 21.2 & 16.2 & 22.7 & 24.2 & 15.8 & 2.86 \\
\hline $\begin{array}{l}\text { Koordinatör öğretmenimiz beceri eğitimi süresince } \\
\text { bizimle ilgileniyor }\end{array}$ & 20.4 & 11.5 & 20.8 & 22.7 & 24.6 & 3.20 \\
\hline $\begin{array}{l}\text { Okulda aldığım muhasebe eğitimi sonucu kendimi } \\
\text { muhasebe ile ilgili belgeleri düzenleyebilecek } \\
\text { seviyede görüyorum }\end{array}$ & 18.1 & 12.7 & 21.9 & 25 & 22.3 & 3.21 \\
\hline
\end{tabular}




\begin{tabular}{|l|c|c|c|c|c|c|}
\hline $\begin{array}{l}\text { Okulumuzun sınıf, ders araç ve gereç vb. donanımları } \\
\text { muhasebe eğitimini karşımamaya yeterlidir }\end{array}$ & 23.1 & 18.1 & 22.3 & 21.2 & 15.4 & $\mathbf{2 . 8 8}$ \\
\hline $\begin{array}{l}\text { Muhasebe kayıtları sırasında kullanılan Tek Düzen } \\
\text { Hesap Planı'nı muhasebe eğitimi için gerekli } \\
\text { buluyorum }\end{array}$ & 13.5 & 13.5 & 26.5 & 29.2 & 17.3 & $\mathbf{3 . 2 3}$ \\
\hline $\begin{array}{l}\text { Mesleki ve Teknik Anadolu Lisesinde aldığım } \\
\text { muhasebe eğitiminin üniversitede alacağım } \\
\text { muhasebe eğitimine faydası olacağını düşünüyorum }\end{array}$ & 20.4 & 11.5 & 19.6 & 20 & 28.5 & $\mathbf{3 . 2 5}$ \\
\hline $\begin{array}{l}\text { Mesleki ve Teknik Anadolu Lisesinden mezun } \\
\text { olmanın iş bulmada bize fayda sağlayacağını } \\
\text { düşünüyorum }\end{array}$ & 20.8 & 9.2 & 20.4 & 20.4 & 29.2 & $\mathbf{3 . 2 8}$ \\
\hline
\end{tabular}

Ankete katılan öğrencilere Mesleki ve Teknik Anadolu Liselerinde verilen muhasebe eğitiminden beklentilerini, memnuniyetlerini ve sorunlarını anlamak amacıyla 5 'li likert ölçeği kullanılarak toplam 16 soru sorulmuştur. Tabloda bulunan rakamlar öğrencilerin verdiği cevapları yüzde (\%) olarak ifade etmektedir. Ayrıca öğrencilerin işaretlediği şıklara puan verilerek(kesinlikle katılmıyorum $=1$, katılmıyorum $=2$, kararsızım $=3$, katılıyorum $=4$ ve kesinlikle katılıyorum=5) ortalama puanlar da hesaplanmıştır (Tablo 4). Dolayısıyla ortalama puanların 3 'ten düşük olması olumsuz, 3'ten büyük olması kısmen olumlu, 4'ten büyük olması ise olumlu olarak düşünülebilir. Maalesef ortalama puanı 4 'ten büyük hiçbir soru yoktur.

Ortaya çıkan sonuçlara göre öğrenciler okuldaki kültür derslerinin onları hayata hazırlamadığı (2.82), muhasebe kitaplarının yetersizliği (2.92), beceri eğitimi sırasında gerçek defterlere kayıt yapamadıkları (2.86) ve okuldaki araç gereçlerin ihtiyacı karşılamadığı (2.88) konusunda görüş bildirmişlerdir. Öğrencilerin kısmen memnun oldukları konular ise, aldıkları muhasebe eğitiminin kalitesi, ders saatlerinin yeterli düzeyde olması, beceri eğitiminin düzeyi, koordinatör öğretmenlerin ilgisi, eğitim sonrası yeterlilikleri ve iş bulacaklarına olan inançları konularıdır (Ortalama puanlar 3’ün biraz üstündedir).

\section{SONUÇ VE ÖNERILER}

Ankete katılan öğrencilerin verdileri cevapların sonucunda, Mesleki ve Teknik Anadolu Liselerinde verilen muhasebe eğitiminde birtakım sorunların olduğu anlaşılmaktadır. Bu sorunları özetleyecek olursak;

- Beceri eğitimi alınan kurumlar muhasebe alanı ile ilgili değildir.

- $\quad$ Beceri eğitimi yapılan kurumları belirlerken okul yönetimi ve öğretmenler, öğrencilere yeteri kadar yardımda bulunmamaktadırlar. çalıştırılmaktadır.

Beceri eğitimi yapan öğrencilerin bir kısmı, muhasebe dışı işlerde sevmemektedir.

Mesleki ve Teknik Anadolu Liselerinde okuyan öğrenciler muhasebeyi

- $\quad$ Mesleki ve Teknik Anadolu Liselerindekikültür dersleri kısmen yetersizdir. 
- $\quad$ Mesleki ve Teknik Anadolu Liselerindekimeslek dersleri muhasebe eğitimi için k1smen yetersizdir.

- Mesleki ve Teknik Anadolu Liselerindeki öğrenciler muhasebe eğitimi için kaynak sıkıntısı çekmektedir.

- $\quad$ Beceri eğitimi sırasında öğrencilere pratik yapma imkanı verilmemektedir.

- Mesleki ve Teknik Anadolu Liselerindekisınıf, ders araç ve gereç vb. donanımları muhasebe eğitimini karşılamada yetersizdir.

Bu sorunlardan yola çıkarak bazı çözüm önerileri geliştirilebilir. Bunlar;

- $\quad$ Okullar, öğretmenler, öğrenciler ve kurumlar daha koordineli çalışmalı ve öğrencilerin beceri eğitimi aldığı kurumların tamamı muhasebe alanı ile ilgili olmalıdır.

- $\quad$ Okul yönetimi ve öğretmenler, beceri eğitimi alınacak kurumları belirlemede, öğrencilere daha fazla yardımda bulunmalıdırlar.

- Okul yönetimi ve öğretmenler beceri eğitimi alınan kurumlarla iletişime geçerek, öğrencilerin bu kurumlarda, sadece muhasebe alanında çalışmalarını ve daha fazla pratik yapma imkanını sağlamalıdırlar.

- $\quad$ Okul yönetimi ve öğretmenler, öğrencilere muhasebeyi sevdirecek çalışmalar ve etkinlikler yapmalıdırlar. yapılmalıdir.

Kültür ve muhasebe eğitimi derslerinin kalitesini attırıcı birtakım çalışmalar

- Mesleki ve Teknik Anadolu Liselerindeki muhasebe eğitimi müfredatına uygun yeni ders kitapları yazılmalıdır.

- Mesleki ve Teknik Anadolu Liselerindeki sınıf, ders araç ve gereç vb. donanımları muhasebe eğitimini karşılayacak şekilde yenilenmelidir.

\section{7. ÇALIŞMANIN SINIRLILIKLARI}

Çalışmada, frekans ve yüzde dağılımı ile ortalamalar gibi istatistiki yöntemlerle analizler yapılmıştır. İleriki çalışmalarda ortalamaların değişkenlere göre farkı ve faktör analizleri gibi daha ayrıntılı analizler yapılabilir. Çalışmada kullanılan veriler sadece Ağrı ve Erzurum ticaret meslek liselerinde öğrenim gören öğrencilerden elde edilmiştir. Çalışmada anketlerden yola çıkarak sadece öğrenci görüşlerine yer verilmiştir. İleriki çalışmalarda örneklem büyüklüğü genişletilebilir ve öğrenciler dışında öğreticilerin de görüşleri de alınabilir. 


\section{KAYNAKLAR}

Akbulut, Halim-Pekkaya, Mehmet - Aksakaloğlu, Hakan (2014), "Meslek Mensuplarının Bakış Açısıyla Ticaret Meslek Liselerindeki Muhasebe Eğitimi: Bursa İli Üzerine Bir Uygulama", Muhasebe ve Finansman Dergisi, ss.73-92.

Akman, H. Nazlı - Muğan, C. Ş. (2004),"Muhasebe Eğitiminde Öğretim ve Öğrenim Yöntemleri ile Ders Başarısı Arasındaki İlişki", XXIII. Türkiye Muhasebe Eğitimi Sempozyumu. Antalya.

Aksakaloğlu, Hakan (2013),Ticaret Meslek Liselerinde Verilen Muhasebe Eğitiminin Muhasebecilik Mesleğine Uygunluğu: Bursa İli Örneği Yayınlanmamış Yüksek Lisans Tezi, Bülent Ecevit Üniversitesi Sosyal Bilimler Enstitüsü.

Atmaca, Metin-Çoşgun, Nurcan (2014),"Çanakkale Onsekiz Mart Üniversitesi'ne Bağlı Meslek Yüksek Okullarında Muhasebe Eğitimi Alan Öğrencilerin Motivasyonlarının ve Beklentilerinin Değerlendirilmesine Yönelik Bir Araştırma", Çankırı Karatekin Üniversitesi İ̈BF Dergisi, 4(1), ss.167 - 184.

Bay, M. M. (2010),MEGEP Kapsamında Ticaret Meslek Liselerindeki Muhasebe Eğitimi Uygulamasında Karşılaşılan Aksaklıkla ve Çözüm Önerileri: Ankara Örneği. Yayınlanmamış Yüksek Lisans Tezi, Gazi Üniversitesi Eğitim Bilimleri Enstitüsü.

Bekçi, İsmail-Titiz, İsmet-Ömürbek, Nuri (2006),"Muhasebe Eğitimi Alan Öğrencilerin Bilgisayarlı Muhasebe Dersine Bakış Açılarına İlişkin Bir Araştırma"Muhasebe ve Finansman Dergisi (29), ss.166-175.

Bonwell, C. Charles - Eison, James (1991),Active Learning. ASHE-ERIC Higher Education Report NO: 1, The George Washington University.

Burnett, Sharon (2010),"The Future of Accounting Education: A Regional Perspective", Jounal of Education For Business, pp.129-34.

Byrne, Marann - Flood, Barbara (2005), "A Study of Accounting Students' Motives Expectations and Preparedness for Higher Education", Journal of Further and Higher Education, 29(2), pp.111-124.

Cottel, P. G. - Millis, B. J. (1993),"Cooperative Learning Structures in the Instruction of Accounting", Issues in Accounting Education, 8(1),pp. 40-60.

Çakır, Nazife - Canbaz, Serdar - Gümüş, Serpil (2014), "Meslek Yüksekokulu Öğrencilerinin Muhasebe Eğitimindeki Algı ve Beklemtilerinin Belirlenmesine Yönelik Bir Araştırma: Uzunköprü MYO Örneği", Pazarlama ve Pazar Araştırmaları Dergisi, 1(2), ss.78-94.

Çamtosun, İ. (2008), Mesleki Eğitim ve Öğretim Sisteminin Güçlendirilmesi Projesi Sürecinde Ticaret Meslek Liselerindeki Muhasebe Eğitiminin Meslek Yüksek Okullarındaki Muhasebe Eğitimine Etkileri: İstanbul'da Bir Alan Araştırması, Yayınlanmamış Yüksek Lisans Tezi, Marmara Üniversitesi Sosyal Bilimler Enstitüsü. 
Çiftçi, Yavuz - Çemrek, Nermin (2018),"Ticaret Meslek Liselerinde Muhasebe Eğitimi: Muğla İli'ndeki Meslek Liseleri Üzerine Bir Araştırma", Ömer Halis Demir Üniversitesi İ̈BF Dergisi, 11(1), ss.192-208.

Demirci, M. S. (2007), Ticaret Meslek Liselerinde Staj Yapan Öğrencilerin İşletmelerde Beceri Eğitiminde Karşılaştıkları Sorunlar ve Çözüm Yolları, Yayınlanmamış Yüksek Lisans Tezi, Yeditepe Üniversitesi Sosyal Bilimler Enstitüsü.

Demirkan, Ş. (2001), Muhasebe Eğitim Yöntemleri, XX. Türkiye Muhasebe Eğitimi Sempozyumu.

Erol, Mikail (2004),"Meslek Yüksek Okullarında Muhasebe Eğitimi Alan Öğrencilerin Staj Uygulamasında Karşılaş̧ıkları Sorunlar ve Çözüm Önerileri", Muhasebe ve Finansman Dergisi(21), ss.136-142.

Ertuğrul, İrfan - Özdemir, Serkan (2014), "Muhasebe Dersi Alan Ön Lisans ve Lisans Öğrencilerinin Derse Yönelik Tutumlarının Tespiti: Ege Bölgesinde Bir Uygulama", Niğde Üniversitesi İ̈BF Dergisi, 7(1), ss.204-214.

Gökgöz, A. (2007), Ticaret Meslek Liselerinde Muhasebe Eğitimi Alan Öğrencilerin Stajyerlikte Karşılaştıkları Problemler ve Çözüm Önerileri, Yayınlanmamış Yüksek Lisans Tezi, Sakarya Üniversitesi Sosyal Bilimler Enstitüsü.

Gönen, Seçkin (2016), "Önlisans Düzeyinde Eğitim Gören Öğrencilerin Muhasebe Eğitiminden Beklentilere Yönelik İzmir ve Denizli İllerinde Bir Araştırma", Uluslararası Alanya İşletme Fakültesi Dergisi, 8(2),ss. 67-78.

Howieson, Bryan (2003),"Accounting Practise in the New Millennium: Is Accounting Education Ready to Meet Challenge? ", The British Accounting Review,pp.69-103.

İmamoğlu , Mustafa (2010), Ortaöğretim Kurumlarında Muhasebe Eğitimi ve Karşılaşılan Sorunların İncelenmesi. Yayınlanmamış Yüksek Lisans Tezi, Marmara Üniversitesi Sosyal Bilimler Enstitüsü.

Kalmış, H - Yılmaz, B. B. (2004), Lisans Seviyesindeki Muhasebe Eğitiminin Mevcut Durumu ve Geliştirilmesi İçin Yapılması Gereken Geliştirmeler, XXIII. Türkiye Muhasebe Eğitimi Sempozyumu . Antalya.

Karaca, Merih (2003), Yüksek Okullarda Muhasebe Eğitiminde Karşlaşılan Sorunlar ve Çözüm Yolları. Yayınlanmamış Yüksek Lisans Tezi, Zonguldak Karaelmas Üniversitesi Sosyal Bilimler Enstitüsü.

Kaya, Uğur - Daştan, Abdülkerim (2004), Türkiye'de Lisans Düzeyinde Verilen Muhasebe Eğitiminin Öğrenci Öğretici ve Uygulayıcılar Açısından Değerlendirilmesi. XXIII. Türkiye Muhasebe Eğitimi Sempozyumu . Antalya.

Kaytmaz Balsarı, Çağnur - Aslantürk, Banu Esra (2007), Kavram Haritaları ve Muhasebe Eğitimi. XXVI. Türkiye Muhasebe Eğitimi Sempozyumu . Antalya. 
Kunt, M. (1992), Ticaret Lisesi Öğrencilerinin Denizli İli Muhasebe Bürolarında Yapmakta Oldukları Beceri Eğitimi Uygulamasında Karşılaşılan Sorunlar ve Bunların Okul Başarısına Etkileri. Yayınlanmamış Yüksek Lisans Tezi, Dokuz Eylül Üniversitesi Sosyal Bilimler Enstitüsü.

Otlu, Fikret - Durmuş, Ahmet Fethi - Solak, Bilal (2012), "Meslek Yüksekokulları Muhasebe ve Vergi Bölümlerindeki Muhasebe Eğitimi ve Bölümün Geleceği Hakkında Bir Araştırma: Malatya Meslek Yüksekokulu Uygulaması", Muhasebe ve Finansman Dergisi(55), ss.35-49.

Özgül, N. (1995), İşletmelerde Staj Yapan Meslek Lisesi Öğrencilerine Staj Yaptıkları Kurumların Mesleki Etkilerinin Belirlenmesine Yönelik Bir Araştırma. Yayınlanmamış Yüksek Lisans Tezi, İstanbul Üniversitesi Sosyal Bilimler Enstitüsü.

Özkan, Fatih - Aksoy, Cenk (2015), "Ticaret Meslek Lisesi Muhasebe Bölümü Öğrencilerinin İşletmelerde Beceri Eğitimi Uygulaması, Gaziantep İlinde Bir Alan Araştırması", Bartın Üniversitesi İ.I..B.F. Dergisi, 6(12),ss. 283-305.

Özpeynirci, Rabia - Duman, Haluk - Erdemir, N. Kemal (2004), Lisans Öğrencilerinin Muhasebe Eğitiminin Kalitesini Artırmada Öğrenen Organizasyon Yaklaşımı ve Karaman İ̈BF Araştırması, XXIII., Türkiye Muhasebe Eğitimi Sempozyumu, Antalya.

Pehlivan, Abdülkadir - Karlıklı, Murat (2018),"Ortaöğretim Kurumlarında Verilen Muhasebe Eğitiminin Muhasebecilik Mesleğine Uygunluğunun Değerlendirilmesi", Siyaset Ekonomi ve Yönetim Araştırmaları Dergisi, 6(1), ss.151-165.

Pehlivan, Ebru (2008),Ticaret Meslek Liselerinde Muhasebe Eğitimi Alan Öğrencilerin Memnuniyetini Etkileyen Faktörlerin İncelenmesi, Yayınlanmamış Yüksek Lisans Tezi, Dumlupınar Üniversitesi Sosyal Bilimler Enstitüsü.

Porter, Brenda - Bui, Binh (2010),"The Expectation-Performance Gap in Accounting Education: An Exploratory Study", Accounting Education, pp.23-50.

Sevilengül, Orhan (2016),Genel Muhasebe (18 b.). Ankara: Gazi Kitabevi.

Silverberg, Marsha - Warner, Elizabeth - Fong , Michael - Goodwin, David (2004),National Assessment of Vocational Education. Birleşik Devletler Eğitim Ofisi Bölümü.

Soylu, Selim (2014), Mesleki Açık Öğretim Lisesi Muhasebe Eğitiminde Karşılaşılan Sorunlar ve Çözüm Önerileri, Gazi Üniversitesi Eğitim Bilimleri Enstitüsü.

Sürer, Hüseyin Murat (2007),Ticaret Meslek Liselerinde Muhasebe Eğitimi Muhasebe Eğitiminden Beklentiler ve Karşılaşılan Sorunlar, Yayınlanmamış Yüksek Lisans Tezi, İstanbul Üniversitesi Sosyal Bilimler Enstitüsü.

Şengel, Salim (2010),"Sürekli Muhasebe Meslek Eğitiminin Önemi ve Bir Değerlendirme", Muhasebe ve Finansman Dergisi(47), ss. 81-94. 
Teixeira, Claudia - Gomes, Delfina - Borges, Janete (2015),"Introductory Accounting Students' Motives, Expectations and Preparedness for Higher Education: Some Portuguese Evidence", Accounting Education, 24(2), pp.123-145.

Tuğay, Osman (2014),"Muhasebe Dersi Alan Öğrencilerin Muhasebe Dersine Yönelik Algıları ve Muhasebe Öğretim Elemanlarından Beklentileri Üzerine Mehmet Akif Ersoy Üniversitesinde Bir Araştırma", Eskişehir Osmangazi Üniversitesi İIBF Dergisi, 9(3), ss.49-68.

Tuğay, Osman - Ömürbek, Vesile (2014),"Meslek Yüksekokullarında Verilen Muhasebe Derslerinin Uygulmada Kullanılma Düzeyi ve Yeterliliği Üzerine Bir Araştırma", Niğde Üniversitesi İ̈BF Dergisi, 7(3), ss.53-74.

Uzay, Şaban (2005, Ocak),"Muhasebe Meslek Stajyerlerinin Sorunları ve Beklentileri: Bir Araştırma",Muhasebe ve Finansman Dergisi, Sayı:25

Yardım, Ersin (2009), Ortaöğretimde Muhasebe Eğitiminin MEGEP ile Yeniden Yapılandırılması Sonrası Öğrenci ve İşveren Memnuniyetinin İncelenmesi, Yayınlanmamış Yüksek Lisans Tezi, Dumlupınar Üniversitesi Sosyal Bilimler Enstitüsü.

Yılmaz, Y. (2011),I̧şletmelerdeki Beceri Eğitimi Uygulamasının Muhasebe Eğitimine Katkısı ve Erzurum İl Genelindeki Ticaret Meslek Liselerinde Muhasebe Eğitimi Alan Öğrenciler Üzerinde Bir Uygulama, Yayınlanmamış Yüksek Lisans Tezi, Atatürk Üniversitesi Sosyal Bilimler Enstitüsü.

Zamanianfar, Leila - Hee Monasojdehe (2014),"Accounting Education and Expectation of Accounting Professionals",Indian Jounal of Fundamental and Applied Life Sciences , 4(1), pp. 298-305. 